\title{
新潟ガス田のガス附随水の化学的性質の特殊性
}

\author{
室 住 正 世**
}

(昭和 34 年11月 28 日受理)

\section{Abnormal Characteristics of Brine Water in the Niigata Natural Gas Field}

\author{
Masayo MUROzUMI
}

\begin{abstract}
Brine from Niigata natural gas field has the abnormal characteristics in the chemical composition of dissolved material and in the isotopic composition of hydrogen of water molecule.

$\mathrm{Na} / \mathrm{Cl}$ of Niigata brine has extraordinarily smaller value than that of sea water and other brines. The deuterium content determined by T. Chitani and Y. Horibe has abnormally decome impoverished in Niigata brine. The ordinary brines have a deuterium content that is comparable to that of sea water.

These facts mean that original Niigata brine has been contaminated by much chloride- and much protium-bearing water during geological ages.
\end{abstract}

\section{緒言}

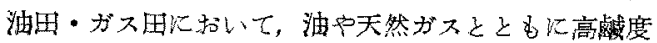
の塩水が湧出するが，この種の附随水恃，油や天然がス

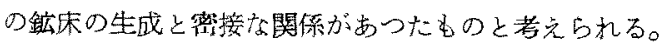
この種の附随水が含有する化学成分の組成は，一般心 $\mathrm{SO}_{4}{ }^{2-}$ が少なく, $\mathrm{Cl}^{-}, \mathrm{HCO}_{3}-$ 㕲よび $\mathrm{Na}^{+}$を主成分と L、I- $\mathrm{Br}^{-}$および $\mathrm{HBO}_{2}$ 等の微量成分の含有量が多 く，他の地下水や温泉・鉱泉水とは，かなり違つた性格 を示すものであることがよく知られている。

この論交では，本邦备地㕍の附随水の化学的性犋，士 なわち險陽雨主要成分である $\mathrm{Cl}^{-}$と $\mathrm{Na}^{+}$の含有量比! リバルによる比）を既発表の資料によつて統計的に処理 し，吉附随水が一般の温泉・鉱泉と違つた $\mathrm{Na}^{+} / \mathrm{Cl}^{-}$ の值をすつことを諭じ，ついで新潟がス田の附随水が，他 の油田やガス田の附㳡水とはかなり相違した $\mathrm{Na}^{+} / \mathrm{Cl}^{-}$ の值をあつものであることを指摘したい。また承自体の 性筫，す广から水素の同位元素組成について論じ，新潟 ガス田の附随水が軽い水素より成るるので，一般の附随

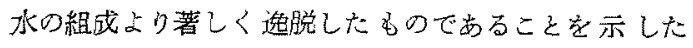
Wo

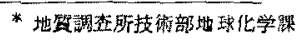

\section{化学組成の特殊性}

まずこの種の附随水炕含有される無機化学成分の組成 について述べれば，本邦の油田・ガス田の $\mathrm{Na}^{+} / \mathrm{Cl}^{-}$の 値は一般に1より大きく，少なくとも海水值 $(0.85)$ よ り小さいことは汪とんどないが(第3図参照)，この図か らもわかる上与に，新渴がス田の附陵水は他のものに較 ベて小さく，特に海水值より小さいものがあるという特 殊性がみいだされる。この種の附随水の起源と，それ以 後の地貿年代の間に附随水が地層中心貯溜されているち らにうけるイオン交撸等による化学組成の変化とを考市 た埸合， $\mathrm{Na}^{+} / \mathrm{Cl}^{-}$の值が海水值より著しく小さいといら

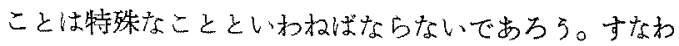

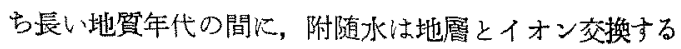
ことによつて，電洒の高い: $\mathrm{Ca}^{2+}$ や $\mathrm{Mg}^{2+}$ を失い, その 代りに $\mathrm{Na}^{+}$を尊入していくと考忩られるから， $\mathrm{Na}^{+} / \mathrm{Cl}^{-}$ の值は時間とともに增大していくである5。つまり，む しその附随水がその雇柲中で, $\mathrm{Na}^{+} / \mathrm{Cl}^{-}$の值が海水值よ り著しく小さい特殊な塩水によつて，混合作用をうける よ5なことがないなら，附随水の $\mathrm{Na}^{+} / \mathrm{Cl}^{-}$の值は年代 の経過とともに当初の值より增大して，現在の一般附随 水のる $\mathrm{Na}^{+} / \mathrm{Cl}^{-}$の值に至つたと考えられよう。した 
がつて新潟ガス由，特に G 4 拈よび G 5

層の附随水の $\mathrm{Na}^{+} / \mathrm{Cl}^{-}$の值が, 一般の附

第 1 図盐水の分類

随水汇較べ著しく小さく，特に海水值上

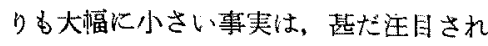
るべきことであつて、この洅兽に发胎す る附随水のガス叙本生成当初の性留が他 の場合と㟟なつていたのか，または地貿

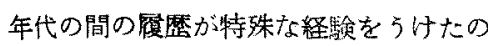
か、どちらかを示しているものといえよ

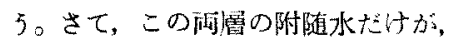

(1) 寺の上下層の附随水, 拉よび一般 附随水々, ガス鉱床生成当初の起 源を異にしているのか

(2) 鉣本生成後に特別な外的影徬を5 けて化学組成に偏りを生じたもの

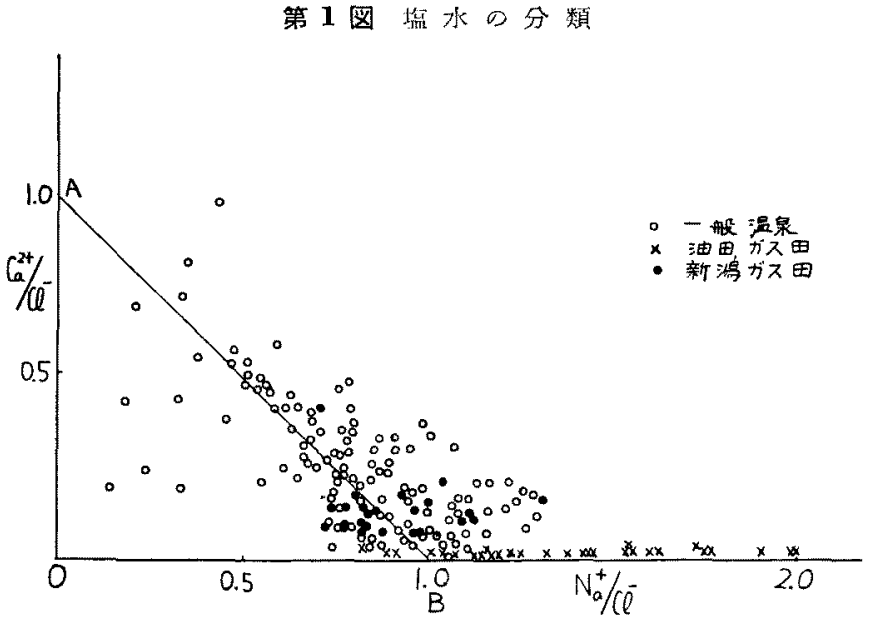
か

については，本墖交にのべる統計的考察では明らかにす ることのできないことであつて，地質学の分野の証继を 併せ若えて解釈されるべきである。しかしこ〉て指摘さ れる附随水の特殊性は，同ガス田に関与る研究江対し雪 要な鍵となり得るむのである。

まず温泉・鍍泉をふくめていからる「塩水」と呼ばれ るるののなかで, 附随水が 1 グループとして分頪される $\mathrm{Na}^{+} / \mathrm{Cl}^{-}$の值をもつていることを示すが，続計の資糊と しては温泉・鉱泉については日本鉣泉誌（淖生省大臣官 房国立公園部編，昭和 29 年)により，また油田ガス田

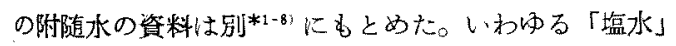
の性質として温泉・鉱泉に対して次の梘準を仮りに設定 した。

A) $\mathrm{Cl}^{-}$含有量が大きいとい5梘準で，他の陰イオン の含有量の多少は問わず, $\mathrm{Cl}^{-}$含有量が $1 \mathrm{~g} / l$ 以 上のる。

B) $\mathrm{Cl}^{-}$舍有率が大きいとい与規準で，たとえ $\mathrm{Cl}^{-}$含 有量が $1 \mathrm{~g} / l$ 以下でも， $\mathrm{Cl}^{-}$が陰イオン組成の 80 \%(ミリバル組成)を越えるもの。

だし，A，B）はそれぞれおよそのものであるから， この㚘準にはずれていても，それに近いるのは採用し た。このA，B）のいずれか鲖うるのを抽出し， そ れらの $\mathrm{Na}^{+} / \mathrm{Cl}^{-}$と $\mathrm{Ca}^{2+} / \mathrm{Cl}^{-}$の值を計算した。

第 1 図は, $\mathrm{Na}^{+} / \mathrm{Cl}^{-}$の值を蓝軸㣗, $\mathrm{Ca}^{2+} / \mathrm{Cl}^{-}$の值を緹 朝にとつて塩水の化学組成を示したすのである。したが つてこの図ではA点は $\mathrm{Na}^{+} / \mathrm{Cl}^{-}=0, \mathrm{Ca}^{2+} / \mathrm{Cl}^{-}=1.0$ すな わち陽イオンが $\mathrm{Ca}^{2+}$ のみよりなるものを，B点は陽イ オンが $\mathrm{Na}^{+}$のみよりなるものを示している, 直線 $\mathrm{AB}$ 上 の子のは $\mathrm{Na}^{+} / \mathrm{Cl}^{-}+\mathrm{Ca}^{2+} / \mathrm{Cl}^{-}=1.0$ すなわち $\mathrm{Na}^{+}$と $\mathrm{Ca}^{2+}$ の和がちようど $\mathrm{Cl}^{-}$に当量のものである。三角形 $\mathrm{AOB}$
内のものは $\mathrm{Cl}^{-}$に対し $\mathrm{Na}^{+} と \mathrm{Ca}^{2+}$ の和が不足するむ ので,特に蕆点 $\mathrm{O}$ に近いものは酸性泉である。直線 $\mathrm{AB}$ 上り外側のものは $\mathrm{Cl}^{-}$飞対し $\mathrm{Na}^{+} と \mathrm{Ca}^{2+}$ の和が当量

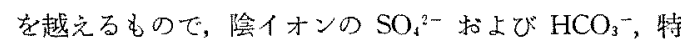
に後者の容存量が多いものである。この第 1 図は、溫度 の毛つ要菜祦いて，化学組成によつて塩水を分類した こととなる。この図化よつて附随水と温泉・踤泉々の差 が明膫である。才なわち一般の温泉・鉣泉は $\mathrm{Na}^{+}$と $\mathrm{Ca}^{2+}$ の网成分者有し, $0.9<\mathrm{Na}^{+} / \mathrm{Cl}^{-}+\mathrm{Ca}^{2+} / \mathrm{Cl}^{-}<1.1$

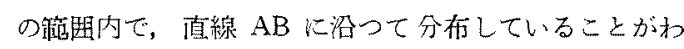
かる。こ机対し一般の附随水は底辺 $\mathrm{OB}$ 上の延長上 に分布していることがわかる。つまり一般离附随水は $\mathrm{Cl}^{-}$に対し $\mathrm{Ca}^{2+}$ をとんど久き，そのかわりに $\mathrm{Na}^{+}$ が著しく多い水であることがかかる。さ的ての図では, 新潟ガス田の附随水印で示してあるが，他の附随水 に較べて $\mathrm{Na}^{+}$が著しく少なく、 $\mathrm{Ca}^{2+}$ が著しく多い特殊 性がみいだされる。さて一般の附随水が $\mathrm{Ca}^{2+}$ を欠いた $\mathrm{OB}$ 線上飞分布しているのは，鉱床生成当初の附随水の 組成が，がに第2図のEまたはHで表わされるもので あつたとしても，長い地留年代の間に $\mathrm{Ca}^{2+}$ が地層とイ オン交換し $\mathrm{Na}^{+}$を溶出した結果，この図の矢印の方向， OB 軸飞接するように組成が变化したためであるう。

さて一般の附随水汇較心，新舅ガス田，主として市街 地の G 4 拈よび G5 層の附随水の化学組成が, いが 異なつているかについて検討してみ上う。第 3 图は, $\mathrm{Na}^{+} / \mathrm{Cl}-$ の值を縱軸沉, $\mathrm{Cl}^{-}$竖度を横軸にとつて, 同ガ ス田の各層, 各年産の附随水の性資を示したるのであ る。資料は板谷実平氏の厗文扣よび新潟県の研先結秲 に上つた。この図にはな招一般附随水の性質も示して あるがここれらのものと比皎して新潟がス田の附随水の 
第 2 国油国ガス囦塩水の組成变化の想定图

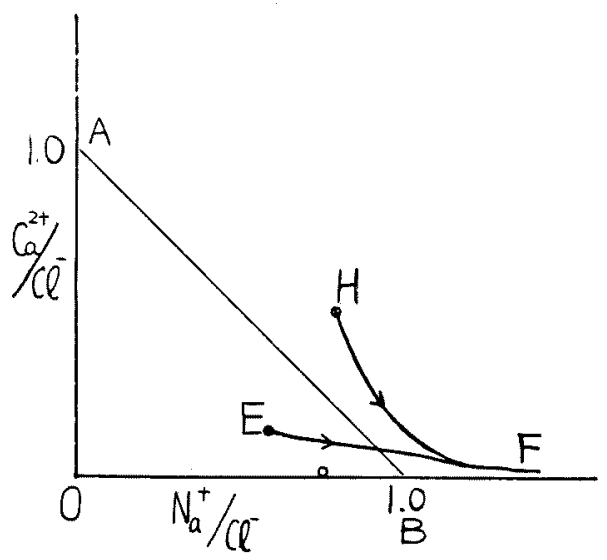

$\mathrm{Na}^{+} / \mathrm{Cl}^{-}$の值が, $\mathrm{Cl}^{-}$漊度の全城にわたつて著しく小さ いことがかかる。また一般の附随水では， $\mathrm{Cl}^{-}$濃度が増 大すると $\mathrm{Na}^{+} / \mathrm{Cl}^{-}$の值が減少し，海水值に近づく傾向 があるが、新潟ガス由においてはいささか傾向を異にし ており, $\mathrm{Cl}^{-}$婊度が $3 \sim 10 \mathrm{~g} / l$ の間のものに, $\mathrm{Na}^{+} / \mathrm{Cl}^{-}$ が海水值上り小さいものがあるという特殊性があり, 特 に $\mathrm{Cl}^{-}$㴞度が $5 \sim 10 \mathrm{~g} / l$ のものは $\mathrm{Na}^{+} / \mathrm{Cl}^{-}$の值が小さ いものが多い。ところが $\mathrm{Cl}^{-}$濃度がこの両側のむのは, ともに $\mathrm{Na}^{+} / \mathrm{Cl}^{-}$の值が大きく, や〉一般附随水の性貲 に近ついている。すなわち特殊な化学組成の附随水は, $\mathrm{Cl}^{-}$瀑度が主として 3〜 $10 \mathrm{~g} / l$ のものであることがわか Ђo

つぎにこれら附随水の $\mathrm{Cl}^{-}$浪度と，地畨との関俰を 求めてみよ5。板谷春平氏によつて明らかなように, 新

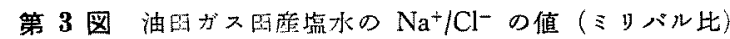

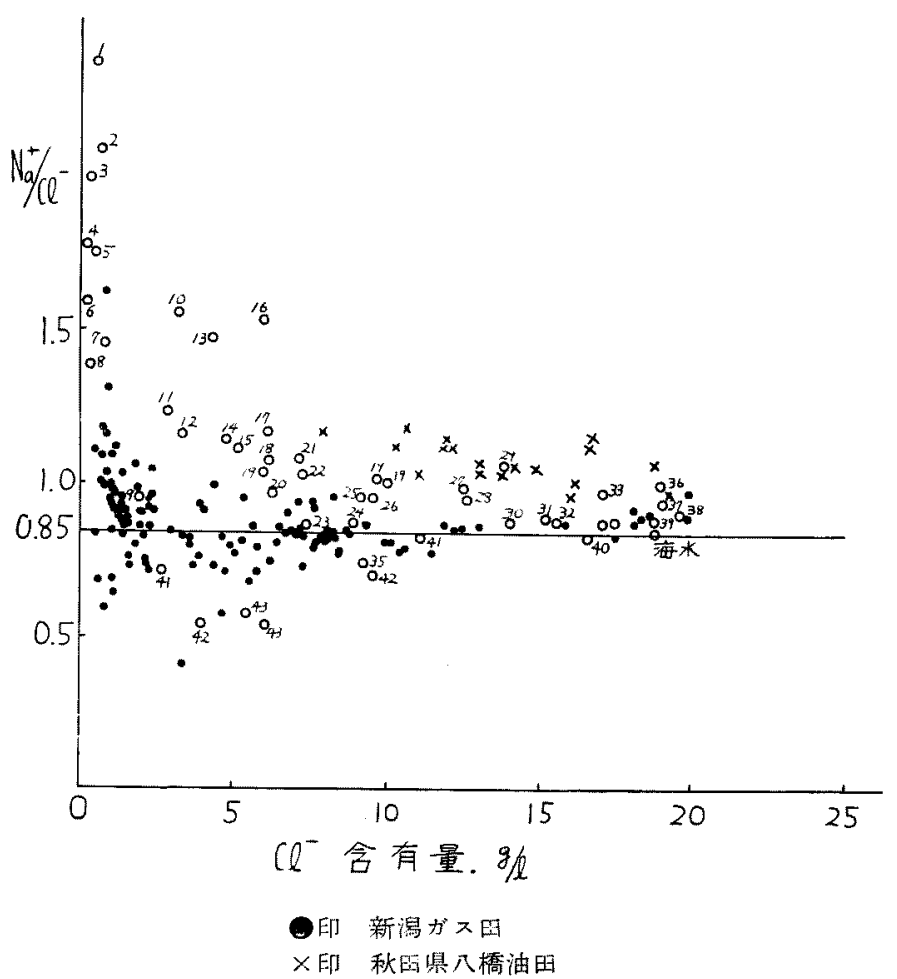

\begin{tabular}{|c|c|c|}
\hline 15 & 声 & (北㵀道) \\
\hline 16 & 19 & (北㵀道) \\
\hline 17 & 层 & （北湤道） \\
\hline 18 & 移 & (北袢道) \\
\hline 19 & F & (山 形) \\
\hline 20 & 梨 & (北篧道) \\
\hline 21 & 增 & (北售道) \\
\hline 22 & 需 & （北摊道） \\
\hline 23 & 野 & (F 淘) \\
\hline 24 & 艮万部 & (北被道) \\
\hline 25 & 高屋芯中 & (官 赫) \\
\hline 26 & 被 & （宦 䐀） \\
\hline ח & 厚 & (北澧通) \\
\hline & 平 利 & (棐 氛) \\
\hline
\end{tabular}

29 等 鼬(秋田)

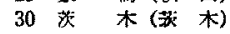

31 石 狩 (北湤道)

32 㨁江津 (新 鼬)

33 和田(秋田)

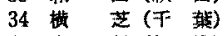

35,41 岩 船 (新 潟)

36 千㙓市(干宾)

37 内田 (千 热)

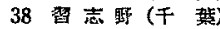

39 聚 金 (千 藻)

40 海老 江 (富 出)

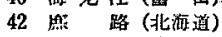

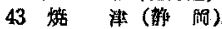

渴ガス田においては深筫はど $\mathrm{Cl}^{-}$

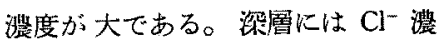
度が大で, $\mathrm{Na}^{+} / \mathrm{Cl}^{-}$の值も他の附随 水よりは小さいが，海水值よりは大 きく，まずまず一般性を備点た附随 水が存在し，浅層には $\mathrm{Cl}^{-}$濃度は 小さいが， $\mathrm{Na}^{+} / \mathrm{Cl}^{-}$の值については 一般性を当つ附随水む存在してい る。ところがこれらの一般性をもつ た滓淡 2 附随水の肧胎する中間の層 に, 特殊な化学的性質をるつ附随水 がサンドイっチ状に分布しているこ とがわかるのである。この特殊な附 随水の存在寸る尿は，主として市街 地の G 4 および G 5 層と呼ばれる bのであつて，このよ5に層位によ つて特殊性が明瞭に区別されること は，注目に値することといえよう。 さてこのよ $5 k ~ \mathrm{Na}^{+} / \mathrm{Cl}^{-}$の值を 減少せしめる原因として，先にあげ たむのの5ち，鉱床生成後の外的影 制によつて組成の偏りを5けたとす る場合を参えてみよ5。

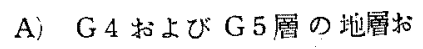

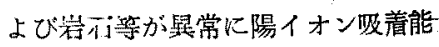
が大で， $\mathrm{Na}^{+}$を著しく吸着したすの とすれば，附随水の $\mathrm{Na}^{+} / \mathrm{Cl}^{-}$の值 は小さくなり得よ5が,この場合に は $\mathrm{Na}^{+}$よりは吸着され易い他の陽 イオン $\mathrm{Ca}^{2+}, \mathrm{Mg}^{2+}$ 扣よび $\mathrm{K}^{+}$等が 多䁷溶存していることは不可解で 


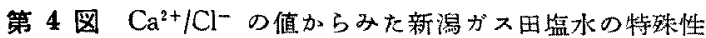

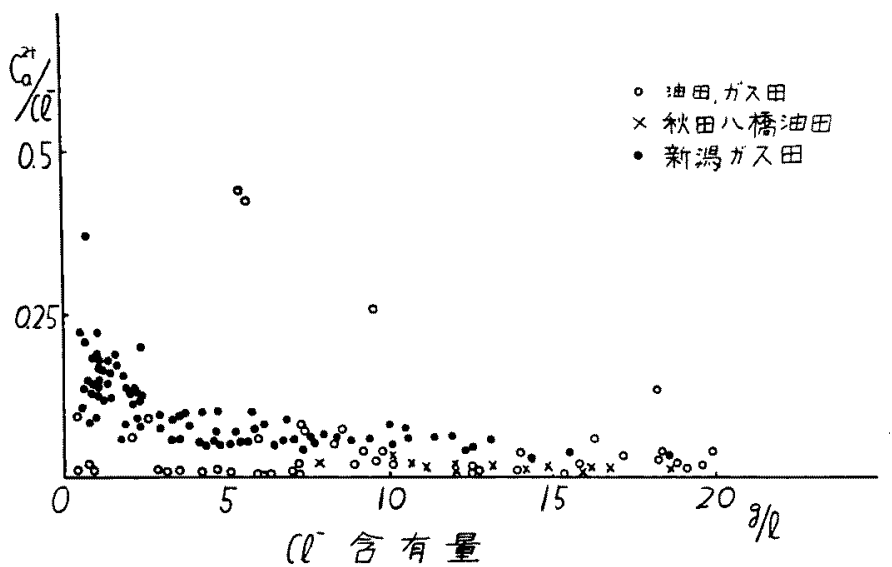

第 5 図 $\mathrm{Mg}^{2+} / \mathrm{Cl}^{-}$の値からみた新潟がス田程水の特殊性

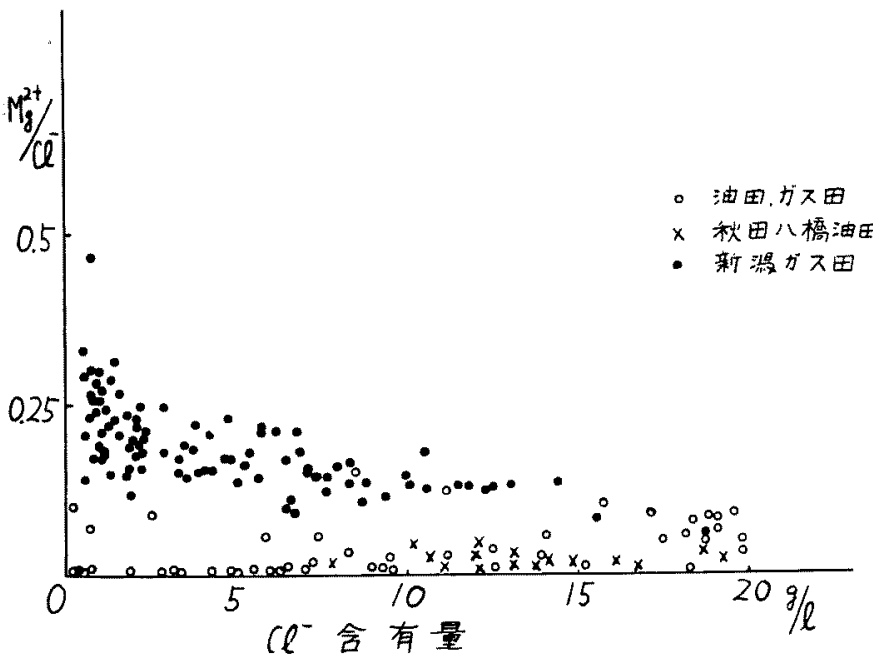

は、 $\mathrm{Ca}^{2+}, \mathrm{Mg}^{2+}$ および $\mathrm{K}^{+}$等がな拈 多く浴存することからして，余り占い 時代ではないと考完られるであるら。

\section{水素の同位元素組成より 見た特殊性}

いままで附随水に含有される化学成 分の量比にもとついて，新渴ガス田の 附随水の特殊性を諭じてきたが，次に 附随水の水自体の特殊性を，水素の同 位元劫組成によつて検討してみよ5。 千谷利三氏等"゙よつて新舄ガス田の 附随水の雷水素橴度が第 1 表にみる 5 に測定されているが，同ガス田の附 随水の西水素灌度は，队外の他地域の 附随水と比較して著しく小さいことが わかる。

新渴ガス田が生成した当時の海水の 水素の同位元偿組成は，懪在の海水の ものと変らないと考光られるから，も。 し新潟ガス田が海成のものであるな 5, 附随水の同位元烮組成は海水のそ れにおよそ一致寸べきである5し， た淡水成ないし汽水成のものであつ て束，現在の淡水の組成に較へ，重水 素が成少して第 1 表の数值が㷛となる ことはあり得ないであるう。内外の他 地域の附随水の雷水菜の渐度が，は之 えど游水のそれに等しいのに較べ，新 鼬ガス日の附随水が特に軽い水素でで きており，しかも河水よりも軽い真の 値をむつということは，特に这目しな

ある。すなわら第 4 図および第 5 図に示したように,一般 の附随水に較へ新潟ガス田の $\mathrm{Ca}^{2+} / \mathrm{Cl}^{-} お よ ひ ゙ ~ \mathrm{Mg}^{2+} / \mathrm{Cl}^{-}$ の傎が著しく大きいとい5ことは，吸着現舆によつて $\mathrm{Na}^{+} / \mathrm{Cl}^{-}$が減少したと説明することを困難にしているよ うに考完られるが，な和今後战土鉱物の吸着作用に関し 一層の研究が必要といえるであろ5。

B) このG4拈よび G5層の附随水の特殊性は, $\mathrm{Na}^{+} / \mathrm{Cl}^{-}$の值が著しく小さく, かつ $\mathrm{Ca}^{2+} / \mathrm{Cl}^{-}, \mathrm{Mg}^{2+} / \mathrm{Cl}^{-}$ 括よび $\mathrm{K}^{+} / \mathrm{Cl}^{-}$の值の大きい特殊な塩水が，G 5 層以下 の一般的性格の附随水に混合することによつて生じたと 考觉られないことはない。この場合湿合作用に関与した 塩水の性筫は，第 1 図の $\mathrm{AB}$ 線上ないし三角形 $\mathrm{AOB}$ 内の $\mathrm{Na}^{+} / \mathrm{Cl}^{-}$の值が0.85 より小さい籍用に位置を占め るよらなるのとなるであろう。混合作用の起つた時代
第】表 新渴ガス田の附随水の 重水軎濃度 $\left(\mathrm{dD}_{*}\right)$

\begin{tabular}{|c|c|c|}
\hline $\begin{array}{c}\text { 試料採取澡店 } \\
(\mathrm{m})\end{array}$ & $\begin{array}{c}\text { 温 } \\
\left({ }^{\circ} \mathrm{C}\right)\end{array}$ & $\mathrm{dD}$ \\
\hline 180 & 20 & +0.29 \\
460 & 24 & -2.89 \\
800 & 32 & +-0.93 \\
1500 & & +0.34 \\
\hline
\end{tabular}

$* \mathrm{dD}=\frac{\text { 試料の D/H一東京水道水の } \mathrm{D} / \mathrm{H}(0.0149)}{0.0149} \times 100$

くてはならない特殊性といえるであろう。しかも軽い水 琴よりなる附随水が G4ないし G5 槄に相当する深度 で測定されているといらことは，先の化学組成の問題と 関連し，甚だ興味あることである。すなわ台新渴ガス田 


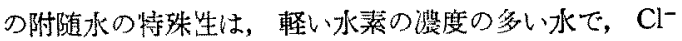

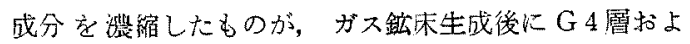
び G5屓を経路として侵入したために生じたるのとす るのが最も考光易い。

\section{結語}

以上のベたように新潟ガス由の附随水は，水自体の性 筫に括いても，溶存する成分の量比において子，他地域 の附随水とは著しく性格を異にしたるのといえる。その 特殊性はガス鉣林が生成した後に，轻い水素の多い水で

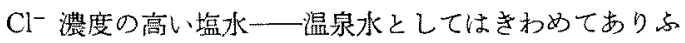
れた性格であるが一によつて淂合されたと考えれば説 明のつくものである。

近时天然ガス採取に伴なう問题がやかましいおり，新 舅がス世旦附随水の示す銠上の特殊性は，人工的な鉱床 の破壦に先立つてすでに自然の変化が行われた，あるい は行秃つつあることを示す事例として，甚だ興味ある ものといえよ5。

本諭文の内管は筆者個人の私見であることを继断りし $-\tau<$ 。
重水热の分析資料さ提供された目京都立大学千谷利三 教授・堀部純男助教授に卸礼申上げるととすに，多くの

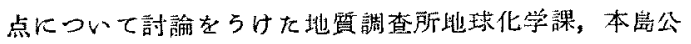
司技管に感謝束上げる。

\section{文献}

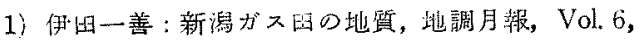
p. $327,1955$.

2) 板谷実平：新潟印内天然ガス付随水 $の$ 化学的研 究, 日本化学蓶誌, Vol. 78, p. 430, p. 434, p. 437, 1957, Vol. 79, p. 900, 1958, Vol. 80, F. 145 , p. $359,1959$.

3) 兼子勝：本邦天然ガ ス鉣床の地監学的研究, 地調 耀告, 第 169 묵, 1956.

4) 本离公司, 他：秋䀦市八橋油由の地化学調查㢳告, 末発表。

5) 地買調查所堀料.

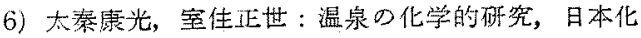
学雑誌, Vol. 77, p. $66,1956$.

7) 太泰康光,他：日本化学会第 8 年会発表緐料。

8) 新潟県：天然ガス調查耀告, 1959.

9）千谷利三・堀部純男・小㷊卓二・小早川美津子： 第 1 回原子カシンポジュウんその他, 質䙵分析, Vol. 6, p. 27, 1956, Vol. 10, p. 40, 1958. 